\title{
ANALISIS VARIABEL-VARIABEL YANG MEMPENGARUHI PERTUMBUHAN EKONOMI DI PROVINSI KEPULAUAN BANGKA BELITUNG TAHUN 2008-2015*
}

\author{
Syamsu Pratama ${ }^{1}$ \\ 1Badan Pusat Statistik Kabupaten Bangka Tengah, Indonesia, syamsu.pratama@bps.go.id \\ Indonesian Journal of Statistics and Its Applications (eISSN:2599-0802) \\ Vol 3 No 2 (2019), 124 - 138 \\ Copyright ( 2019 Syamsu Pratama. This is an open-access article distributed under the Creative \\ Commons Attribution License, which permits unrestricted use, distribution, and reproduction in any \\ medium, provided the original work is properly cited.
}

\begin{abstract}
Economic growth of a region can assess from various aggregate sizes, one of them is GDRP (Gross Regional Domestic Product). Based on theory, GDRP can influenced by several variables, including world commodity prices which have the largest share of GDP, labor force participation rate (LFPR), Human Development Index (HDI), income inequality, open unemployment rate and percentage of the poor. In 2015 Bangka Belitung Islands Province GRDP had a share of around 0.5 percent of Indonesia's GDP. The largest share is West Bangka Regency with 11.46 trillion rupiahs, while the smallest one is East Belitung with 6.112 trillion rupiahs. To find out picture of economic growth and the influence of variable prices of palm oil commodities, LFPR, HDI income inequality, open unemployment and the percentage of the poor on economic growth in the Bangka Belitung Islands Province 2008-2015, the method used is descriptive analysis and panel data regression. The best model for estimating GDRP growth in Bangka Belitung Islands Province in 2008-2015 is the fix effect model with Seemingly Uncorrelated Regression Method. With alpha 5 percent, the variables that significantly influence economic growth are HDI, the percentage of the poor, labor force participation rate (LFPR), income inequality, open unemployment rate and world commodity prices.
\end{abstract}

Keywords: economic growth, human development index, panel regression.

\section{Pendahuluan}

\section{$1.1 \quad$ Latar Belakang}

Produk Domestik Regional Bruto (PDRB) merupakan salah satu indikator dalam menentukan tingkat kemakmuran rakyat suatu daerah. Secara sederhana Produk domestik regional Bruto adalah jumlah selisih antara output dengan input antara di

\footnotetext{
"Received Nov 2018; Accepted Apr 2019; Published online on Jun 2019
} 
suatu daerah. Dengan kata lain PDRB adalah jumlah dari nilai tambah bruto seluruh unit produsen residen ditambah juga pajak seluruh produk (United Nation, 2009).

Berdasarkan data Badan Pusat Statistik, PDRB di seluruh provinsi di Indonesia memiliki kecendrungan meningkat pada periode 2008-2015. Hal ini menunjukan jika secara umum tingkat kesejahteraan masyarakat Indonesia semakin membaik. Bangka Belitung merupakan salah satu provinsi di Indonesia, pada tahun 2015 Provinsi Kepulauan Bangka Belitung memberikan share terhadap PDB Indonesia Sebesar 0,52 persen. Meskipun kontribusi PDRB Provinsi Kepulauan Bangka Belitung terhadap PDB Indonesia tergolong kecil namun Provinsi Kepuluan Bangka Belitung merupakan salah satu daerah yang memproduksi timah dan minyak sawit terbesar di dunia.

Penelitian ini bertujuan untuk mengetahui variabel apa saja yang berpengaruh terhadap pertumbuhan ekonomi di Provinsi Kepulauan Bangka Belitung. Hal ini penting untuk dilakukan sebab Provinsi Kepulauan Bangka Belitung merupakan salah satu penghasil timah dan kelapa sawit terbesar didunia. Sehingga diperlukan penelitian empiris untuk mengetahui variabel apa saja yang berpengaruh signifikan terhadap pertumbuhan ekonomi di Provinsi Kepulauan Bangka Belitung.

\subsection{Landasan Teori dan Penelitian Terdahulu}

Pertumbuhan ekonomi suatu daerah dapat digambarkan dari pertumbuhan PDRB dengan menghilangkan faktor inflasi (harga konstan). (Denison,1962) Dengan kata lain apabila pertumbuhan PDRB atas dasar harga konstan di suatu daerah menunjukan tren positif maka hal itu mencerminkan kondisi perekonomian di suatu daerah lebih baik dari tahun sebelumnya.

Berdasarkan teori, pertumbuhan PDRB di pengaruhi oleh faktor ketenagakerjaan, kualitas sumber daya manusia, kemiskinan dan harga komoditas unggulan di suatu daerah. Ada beberapa indikator yang dapat mencerminkan ketenagakerjaan,beberapa indikator tersebut adalah Tingkat Partisipasi Angkatan Kerja (TPAK) dan Tingkat Pengangguran Terbuka (TPT). Tingkat Partisipasi Angkatan Kerja adalah persentase penduduk usia kerja yang aktif melakukan kegiatan ekonomi dalam kegiatan seharihari dalam suatu periode tertentu sedangkan TPT adalah persentase pengangguran dari angkatan kerja (Adioetomo dan Samosir, 2010).

Indikator yang dapat mencerminkan kualitas sumber daya manusia suatu daerah adalah Indeks Pembangunan Manusia (IPM). IPM terdiri dari tiga indikator yaitu umur panjang dan sehat, pengetahuan dan standar hidup yang layak. Indikator umur panjang dan sehat diwakili oleh indikator harapan hidup saat lahir. Indikator pengetahuan diwakili oleh indikator harapan lama sekoah dan rata-rata lama sekolah. Sedangkan indikator standar hidup layak di wakili oleh pengeluaran perkapita. (United Nation, 2014)

Sedangkan indikator yang menggambarkan kemiskinan dan kesenjangan pendapatan adalah persentase penduduk miskin $\left(P_{0}\right)$ dan gini ratio. Persentase penduduk miskin adalah adalah persentase penduduk yang berada dibawah Garis Kemiskinan (GK) sedangkan gini ratio adalah indeks yang mencerminkan tingkat pemerataan distribusi pendapatan suatu masyarakat. (Todaro dan Smith, 2003)

Pada penelitian sebelumnya tentang pertumbuhan ekonomi menyatakan jika persentase pengangguran dan penduduk miskin berpengaruh negatif terhadap pertumbuhan ekonomi di Provinsi Sumatera Utara dan signifikan pada alpha 5 persen 
(Kalsum,2017), penelitian lain pun menyatakan jika pengangguran pun berdampak negatif bagi pertumbuhan ekonomi afrika selatan (Makaringe dan Hlalefang, 2018). Berdasarkan penelitian empiris indeks pembangunan manusia (IPM) memiliki pengaruh yang signifikan terhadap pertumbuhan ekonomi di nigeria (Aigheyisi, 2013). Sedangkan gini rasio memberikan pengaruh negatif terhadap pertumbuhan ekonomi di China (Tian, 2012).

Penelitian ini menggunkaan Data panel atau yang sering disebut juga pooled data. Data Panel merupakan gabungan antara data time series dan cross section (Gujarati, 2003). Dengan kata lain, data panel merupakan unit-unit yang sama yang diamati pada kurun waktu tertentu. Secara umum, data panel dicirikan oleh T periode waktu $(t=1,2$, $\ldots, \mathrm{T})$ yang kecil dan $\mathrm{N}$ jumlah individu $(\mathrm{i}=1,2, \ldots, \mathrm{N})$ yang besar, tetapi tidak menutup kemungkinan terjadi yang sebaliknya, yakni terdiri dari periode waktu yang besar dan jumlah individu yang kecil. Menurut Greene (2000), keuntungan dasar dari menggunakan data panel dibandingkan data cross section adalah fleksibilitas yang diperoleh peneliti dalam memodelkan individu-individu dengan karakter yang berbeda.

\section{Metodologi}

\section{$2.1 \quad$ Data}

Data yang digunakan dalam penelitian ini merupakan data sekunder yang diperoleh dari publikasi Badan Pusat Statistik (BPS). Untuk mengetahui variabel yang mempengaruhi pertumbuhan ekonomi di Provinsi Kepulauan Bangka Belitung periode 2008-2015, metode analisis yang digunakan adalah regresi data panel. Proses pengolahan dibantu dengan menggunakan software microsoft excel 2016 dan eviews 10.

Variabel dependent dalam penelitian ini adalah pertumbuhan ekonomi di 7 kabupaten/kota di Provinsi Kepulauan Bangka Belitung periode 2008-2015. Sedangkan yang menjadi variabel dependentnya adalah persentase penduduk miskin, gini ratio, tingkat partisipasi angkatan kerja(TPAK), tingkat pengangguran terbuka (TPT), indeks pembangunan manusia (IPM) dan harga crude palm oil dunia periode 2008-2015.

\subsection{Metode Penelitian}

Penelitian ini menggunakan metode statistik deskriptif dan metode statistik inferensia. Penjelasan penggunaan kedua metode tersebut adalah sebagai berikut :

\section{Analisis Deskriptif}

Analisis deskriptif mengacu pada transformasi data-data mentah ke dalam suatu bentuk yang mudah dimengerti dan diterjemahkan (Wibisono, 2003). Metode statistik deskriptif digunakan untuk mendapatkan gambaran umum pergerakan PDRB di tujuh Kabupaten/Kota di Provinsi Kepulauan Bangka Belitung periode 2008-2015. Gambaran umum tersebut ditampilkan dalam bentuk grafik. Proses pengolahan analisis deskriptif pada penelitian ini menggunakan program Microsoft Office Excel 2016. 


\section{Analisis Inferensia}

Analisis inferensia yang digunakan dalam penelitian ini adalah regresi data panel. analisis regresi data panel terdapat dua sifat yakni balanced panel dan unbalanced panel. Namun, penelitian ini menggunakan balanced panel yang berarti jumlah observasi waktu yang di miliki individu sama. Dengan demikian total observasi yang dimiliki adalah sebanyak 56 observasi yang terdiri dari 7 observasi crossection dan 8 observasi waktu. Model regresi yang akan digunakan di dalam penelitian ini adalah sebagai berikut:

$$
\begin{aligned}
& \text { Ln_PDRB }_{i t}=\beta_{0}+\beta_{1} \text { Gini_Ratioit }+\beta_{2} I P M_{i t}+\beta_{3} \text { TPAK }_{i t}+\beta_{4} \text { Persmisit }_{i t}+\beta_{5} \text { TPT }_{i t}+ \\
& \beta_{5} L N \_C P O_{\text {it }}+\varepsilon_{\text {it }}
\end{aligned}
$$

\begin{tabular}{|c|c|}
\hline Variabel & Keterangan \\
\hline Ln_PDRB ${ }_{\text {it }}$ & $\begin{array}{llll}\text { Logaritma } & \text { Natural dari } & \text { PDRB }\end{array}$ \\
\hline & Kabupaten/Kota ke-i pada waktu ke-t \\
\hline Gini_Ratioit & $\begin{array}{l}\text { Kesenjangan Pendapatan } \\
\text { Kabupaten/Kota ke-i pada waktu ke-t }\end{array}$ \\
\hline IPMit & $\begin{array}{l}\text { Indeks Pembangunan Manusia } \\
\text { Kabupaten/Kota ke-i pada waktu ke-t }\end{array}$ \\
\hline TPAK $_{\text {it }}$ & $\begin{array}{l}\text { Tingkat Partisipasi Angkatan Kerja } \\
\text { Kabupaten/Kota ke-i pada waktu ke-t }\end{array}$ \\
\hline Persmisit & $\begin{array}{l}\text { Persentase Penduduk Miskin } \\
\text { Kabupaten/Kota ke-i pada waktu ke-t }\end{array}$ \\
\hline $\mathrm{TPT}_{\text {it }}$ & $\begin{array}{l}\text { Tingkat Pengangguran Terbuka } \\
\text { Kabupaten/Kota ke-i pada waktu ke-t }\end{array}$ \\
\hline LN_CPO it & $\begin{array}{l}\text { Logaritma Natural Harga CPO } \\
\text { Kabupaten/Kota ke-i pada waktu ke-t }\end{array}$ \\
\hline
\end{tabular}

Tabel 1. Variabel Dependent Dan Independent Yang Di Gunakan Dalam Penelitian

Tahapan untuk melakukan analisis regresi data panel dapat dilihat pada Gambar 1. Tahap pemilihan model dari Gambar 1 adalah sebagai berikut :

1. Tahapan pertama adalah memilih model panel terbaik. Model regresi panel yang terbaik dapat berupa common effects model, fixed effects model, atau random effects model. Pada tahapan ini dialkukan beberapa uji statistik untuk menentukan model panel manakah yang terbaik, yaitu uji chow, uji hausman, dan uji LM. 


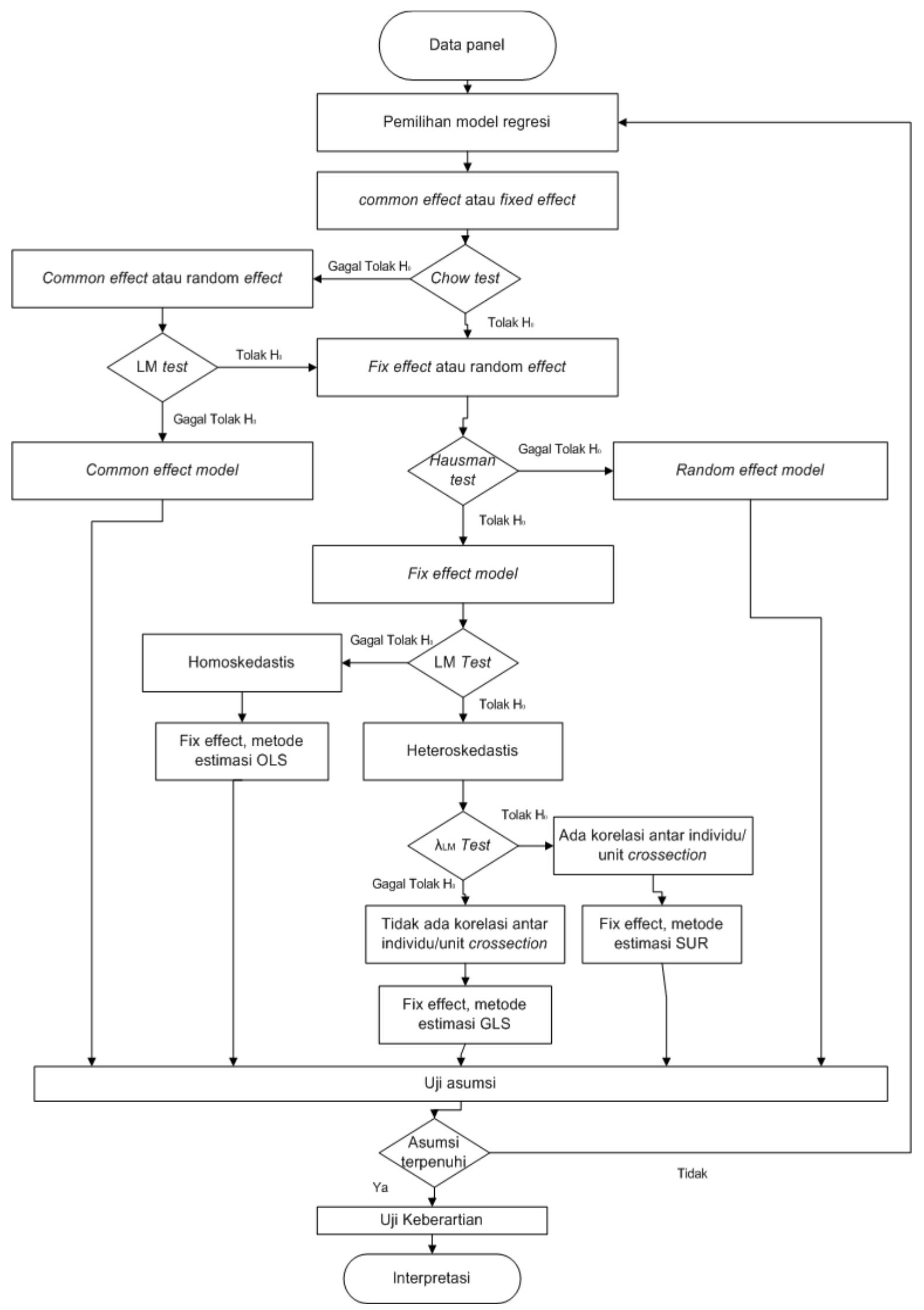

Gambar 1. Alur Analisis Inferensia Regresi Panel 


\section{Uji F (Uji Chow)}

Pengujian signifikansi model fixed effects dilakukan dengan menggunakan uji $\mathrm{F}$ atau disebut juga uji chow. Uji chow digunakan untuk mengetahui apakah teknik regresi data panel dengan fixed effects lebih baik daripada model regresi common effects. Hipotesis dari uji chow dapat dituliskan sebagai berikut :

$\mathrm{H}_{0}$ : Model common effects lebih baik (intercept sama antar individu)

$\mathrm{H}_{1}$ : Model fixed effects lebih baik (intercept berbeda antar individu)

Uji statistik pada uji Chow dapat dituliskan secara matematis sebagai berikut:

$$
F_{\text {hitung }}=\frac{\left(\mathrm{RSS}_{1}-\mathrm{RSS}_{2}\right) /(\mathrm{n}-1)}{\mathrm{RSS}_{2} /(\mathrm{nT}-\mathrm{n}-\mathrm{k})} \sim \mathrm{F}(\mathrm{\alpha} ;(\mathrm{n}-1) ;(\mathrm{nT}-\mathrm{n}-\mathrm{k}))
$$

Dimana $n$ adalah jumlah individu (unit cross section), $T$ adalah periode observasi, $\mathrm{k}$ adalah jumlah variabel dalam model fixed effects, $\mathrm{RSS}_{1}$ adalah residual sum of square common effects model, dan $\mathrm{RSS}_{2}$ adalah residual sum of square fixed effects model.

\section{Uji Lagrange Multiplier (LM)}

Untuk mengetahui jenis model yang akan digunakan salah satunya harus melalui uji heteroskedastisitas dengan menggunakan lagrange multiplier test (LM-Test). $\mathrm{H}_{0}: \sigma_{\alpha}^{2}=0$ (varians dari efek individu $\alpha_{i}$ sama dengan nol/model common effects lebih baik)

$H_{1}: \sigma_{\alpha}^{2} \neq 0$ (varians dari efek individu $\alpha_{i}$ tidak sama dengan nol/model random effects lebih baik)

Uji statistik pada uji LM adalah sebagai berikut:

$$
\mathrm{LM}=\frac{\mathrm{nT}}{2(\mathrm{~T}-1)}\left[\frac{\sum_{\mathrm{i}=1}^{\mathrm{n}}\left(\sum_{\mathrm{i}=1}^{\mathrm{T}} \mathrm{u}_{\mathrm{it}}\right)^{2}}{\sum_{\mathrm{i}=1}^{\mathrm{n}} \sum_{\mathrm{i}=1}^{\mathrm{T}} \mathrm{u}_{\mathrm{it}}^{2}}-1\right]^{2} \sim \mathrm{X}^{2} \alpha, 1
$$

Dimana $\mathrm{n}$ adalah jumlah individu, $\mathrm{T}$ adalah jumlah periode waktu dan $\mathrm{u}_{\mathrm{it}}$ adalah residual dari model common effects. LM akan berdistribusi chi square dengan derajat bebas (df) sebesar 1.

\section{Uji Hausman}

Pengujian untuk mengetahui model manakah yang lebih baik antara model random effects dan fixed effects dapat digunakan uji Hausman. Uji ini didasari oleh adanya ketidak konsistenan dari asumsi yang berlaku pada model random effects, bahwa variabel random effects $u_{i}$ tidak berkorelasi dengan variabel bebas yang ada pada model. Hausman pada tahun 1978 memperkenalkan suatu pengujian yang menyatakan bahwa apabila tidak ada korelasi antara variabel random dengan variabel bebas pada model random effects, maka hasil estimasi OLS pada model fixed effects (LSDV) serta GLS pada model random effects sama-sama 
konsisten, namun pada OLS hasilnya tidak efisien. Akan tetapi, apabila ada korelasi antara random effects dan variabel bebas, maka hasil estimasi OLS tetap konsisten, sedangkan GLS tidak konsisten (Greene, 2000). Hipotesis pada pengujian ini adalah sebagai berikut:

$H_{0}$ : tidak ada korelasi antara $u_{i}$ dan variabel bebas (model random effects lebih baik)

$\mathrm{H}_{1}$ : ada korelasi antara $\mathrm{u}_{i}$ dan variabel bebas (model fixed effects lebih baik)

Statistik uji chi-square yang mengikuti kriteria Wald, yaitu:

$$
W=x^{2}[k]=[b-\hat{\beta}]^{\prime} \hat{\Sigma}^{-1}[b-\hat{\beta}]
$$

Dimana $b$ adalah hasil estimasi koefisien regresi dengan OLS pada model fixed effects, sedangkan $\widehat{\beta}$ adalah hasil estimasi koefisien regresi dengan GLS pada model random effects.

Apabila yang terpilih adalah fixed effects model maka di lanjutkan uji struktur varians-kovarians model. Tujuan dari pengujian ini adalah untuk menentukan metode estimasi yang digunakan. Disini menggunakan LM test untuk menguji asumsi homoskedastis dan Uji $\lambda_{\mathrm{LM}}$ untuk memilih metode estimasi yang digunakan. Berikut Penjelas kedua metode tersebut:

\section{Lagrange Multiplier (LM Test)}

$\mathrm{H}_{0}: \sigma_{\mathrm{i}}^{2}=\sigma^{2}$ (struktur varians-covarians residual homoskedastik)

$\mathrm{H}_{1}: \sigma_{1}^{2} \neq \sigma^{2}$ (struktur varians-covarians residual heteroskedastik)

Secara matematis, statistik uji LM yang digunakan dapat dirumuskan sebagai berikut:

$$
\mathrm{LM}=\frac{\mathrm{T}}{2} \sum_{\mathrm{i}=1}^{\mathrm{n}}\left[\frac{\widehat{\sigma}_{\mathrm{i}}^{2}}{\hat{\bar{\sigma}}^{2}}-1\right]^{2} \sim \chi_{\alpha ; \mathrm{n}-1}^{2}
$$

Dimana $\mathrm{T}$ merupakan jumlah periode waktu, $\mathrm{n}$ adalah jumlah individu, $\widehat{\sigma}_{\mathrm{i}}^{2}$ adalah varians residual persamaan ke-i, dan $\widehat{\sigma}^{2}$ adalah mean square error pada persamaan sistem (secara keseluruhan)

\section{$\lambda_{\text {LM Test }}$}

$\mathrm{H}_{0}$ : struktur varians-covarians residual heteroskedastik dan tidak ada cross sectional correlation

$\mathrm{H}_{1}$ : struktur varians-covarians residual heteroskedastik dan ada cross sectional correlation (Seemingly Uncorrelated Regression)

Kemudian statistik uji yang digunakan adalah:

$$
\lambda_{\mathrm{LM}}=\mathrm{T} \sum_{i=2}^{n} \sum_{j=1}^{i-1} r_{i j}^{2} \sim \chi_{\alpha ; n(n-1) / 2}^{2}
$$

Dimana $\mathrm{n}$ adalah jumlah individu, $\mathrm{T}$ adalah jumlah periode waktu, dan $\mathrm{r}_{\mathrm{ij}}$ adalah residual correlation coefficient antara persamaan ke-i dan ke-j. 
2. Tahapan kedua adalah pengujian asumsi model regresi linier klasik. Asumsi regresi linier klasik yang diuji adalah asumsi normalitas, homoskedastis, nonmultikolinieritas, dan non-autokorelasi (Kutner et.all,2005).

\section{Asumsi Normalitas}

Pemeriksaan kenormalan dapat dilakukan dengan menggunakan grafik P-P plot atau melalui uji statistik formal yakni uji statistik Jarque-Bera (J-B). Pengujian terhadap asumsi kenormalan dapat dilakukan dengan uji Jarque-Bera yang merupakan uji Goodness of fit, yang menguji apakah data sampel memiliki kemencengan dan keruncingan yang cocok dengan distribusi normal.(Hill et.all, 2011)

$\mathrm{H}_{0}:$ error term berdistribusi normal

$\mathrm{H}_{1}$ : error term tidak berdistribusi normal

Metode J-B ini didasarkan pada sampel besar yang diasumsikan bersifat asimtotik. Uji statistik J-B menggunakan perhitungan skewness dan kurtosis. Adapun formulasi statistik untuk menghitung nilai J-B adalah sebagai berikut:

$$
\mathrm{JB}=\mathrm{n}\left[\frac{\text { skewness }^{2}}{6}+\frac{\left({\text { kurtosis }-3)^{2}}^{2}\right.}{24}\right]
$$

\section{Asumsi Non Autokorelasi}

Hipotesis uji DW dapat dituliskan sebagai berikut:

$\mathrm{H}_{0}: \mathrm{E}\left(\mathrm{u}_{\mathrm{i}}, \mathrm{u}_{\mathrm{j}}\right)=0$ (Tidak ada autokorelasi)

$H_{1}: E\left(u_{i}, u_{j}\right) \neq 0, i \neq j$ (Ada autokorelasi)

Di mana u adalah gangguan atau disturbance (error) dari regresi. Adapaun statistik uji DW untuk data panel adalah (Baltagi, 2005):

$$
\mathrm{d}_{\rho}=\frac{\sum_{\mathrm{i}=1}^{\mathrm{N}} \sum_{\mathrm{t}=2}^{\mathrm{T}}\left(\mathrm{u}_{\mathrm{i}, \mathrm{u}} \mathrm{u}_{\mathrm{t}, \mathrm{t}-1}\right)^{2}}{\sum_{\mathrm{i}=1}^{\mathrm{N}} \sum_{\mathrm{i}=1}^{\mathrm{T}}\left(\mathrm{u}_{\mathrm{i}, \mathrm{t}}\right)^{2}}
$$

Dengan ut adalah residual dari regresi dengan fixed effects untuk panel (cross section) $\mathrm{i}, \mathrm{T}$ adalah periode waktu, dan $\mathrm{N}$ adalah jumlah individu. Untuk mendapatkan kesimpulan mengenai apakah terjadi masalah autokorelasi dalam model yaitu dengan membandingkan nilai statistik $d_{\rho}$ dengan batas atas $(d u)$ dan batas bawah $(\mathrm{d}\llcorner)$. Nilai dari du dan $d\llcorner$ dapat dilihat pada tabel Durbin Watson.

\section{Non Multikolinieritas}

Non multikolinieritas merupakan suatu kondisi di mana tidak terdapat hubungan linier antara variabel bebas yang satu dengan yang lain. (Kutner et.all ,2005). Multikolinieritas dapat dilihat dari nilai variance Inflation factor (VIF). VIF dirumuskan:

$$
\mathrm{VIF}=\frac{1}{1-\mathrm{R}_{\mathrm{K}}^{2}}
$$


Dimana $\mathrm{k}=1,2, \ldots, \mathrm{p}-1$ dan $\mathrm{R}_{\mathrm{k}}^{2}$ merupakan koefisien determinasi dari regresi linier berganda ketika $X_{k}$ diregresikan dengan $p-2$ variabel lainnya dalam model.

3. Tahap ketiga adalah uji keberartian model. Yang perlu diperhatikan dalam pengujian keberartian model ini adalah nilai $R$-squared adjusted, hasil uji simultan F dan uij parsial t. Berikut Penjelasan dari R-squared adjusted, hasil uji simultan F dan uij parsial t:

\section{R-squared adjusted}

Koefisien determinasi digunakan untuk mengukur seberapa baik garis regresi sampel cocok pada data, dirumuskan :

$$
\begin{aligned}
& R^{2}=\frac{S S R}{S S T}=1-\frac{S S E}{S S T} \\
& R^{2} a d j=1-\left(1-R^{2}\right) \frac{N T-1}{N T-N-k}
\end{aligned}
$$

Dimana $\mathrm{N}$ adalah jumlah individu cross-section, $\mathrm{T}$ adalah jumlah periode waktu dan $\mathrm{k}$ adalah jumlah variabel independen.

\section{Uji Koefisien Regresi secara Simultan (Uji F)}

$H_{0}: \beta_{1}=\beta_{2}=\ldots=\beta_{k}=0$

$H_{1}$ : minimal salah satu nilai $\beta_{i} \neq 0$, dengan $i=1,2, \ldots, k$

Statistik uji $F$ dihitung dengan formula sebagai berikut:

$$
F_{\text {hitung }}=\frac{\mathrm{MSR}}{\mathrm{MSE}}=\frac{\mathrm{SSR} /((\mathrm{k}+\mathrm{N})-1)}{\mathrm{SSE} /(\mathrm{NT}-(\mathrm{k}+\mathrm{N}))}
$$

Dimana $\mathrm{k}$ adalah jumlah variabel independen, $\mathrm{N}$ adalah jumlah individu, dan $\mathrm{T}$

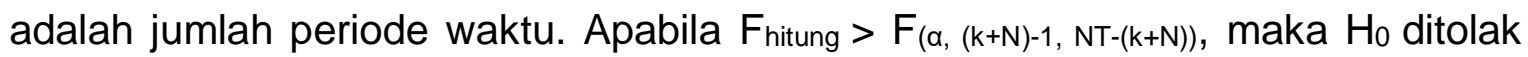
yang berarti minimal ada satu satu variabel independen yang signifikan berpengaruh terhadap variabel dependen.

\section{Uji Koefisien Regresi secara Parsial}

Hipotesis untuk pengujian koefisien regresi secara parsial adalah:

$\mathrm{H}_{0}: \beta_{\mathrm{i}}=0$

$H_{1}: \beta_{i} \neq 0$, dengan $i=1,2, \ldots, k$

Statistik uji yang digunakan adalah statistik uji t-student yang dirumuskan sebagai berikut:

$$
\text { thitung }=\frac{\widehat{\beta}_{i}}{\operatorname{se}\left(\hat{\beta}_{i}\right)}
$$

$\widehat{\beta}_{\mathrm{i}}$ adalah nilai penduga parameter ke-i, se $\left(\widehat{\beta}_{\mathrm{i}}\right)$ adalah simpangan baku dari nilai penduga parameter ke-i. Hipotesis null ditolak jika thitung $>F_{(\alpha,(k+N)-1, N T-(k+N))}$ atau Hipotesis null ditolak jika nilai $p$-value lebih kecil dari $\alpha$.

4. Tahap ke empat adalah interpretasi. Pada tahapan ini dilihat seberapa besar pengaruh variabel independen terhadap variabel dependen dengan menggunakan nilai koefisien $\beta$ setiap variabel independen. 


\section{Hasil dan Pembahasan}

\subsection{Analisis Deskriptif}

Pada Gambar 2 memperlihatkan kondisi PDRB atas dasar harga konstan Kabupaten/ Kota di Provinsi Kepulauan Bangka Belitung pada tahun 2008-2015. Pada Gambar 3 dapat diketahui PDRB Kabupaten/Kota di Provinsi Kepulauan Bangka Belitung pada periode 2008-2015 cukup bervariatif. Pada periode 2008-2015 Kabupaten yang memiliki PDRB tertinggi adalah Kabupaten Bangka Barat. Sedangkan Kabupaten yang memiliki PDRB terkecil adalah Belitung Timur.

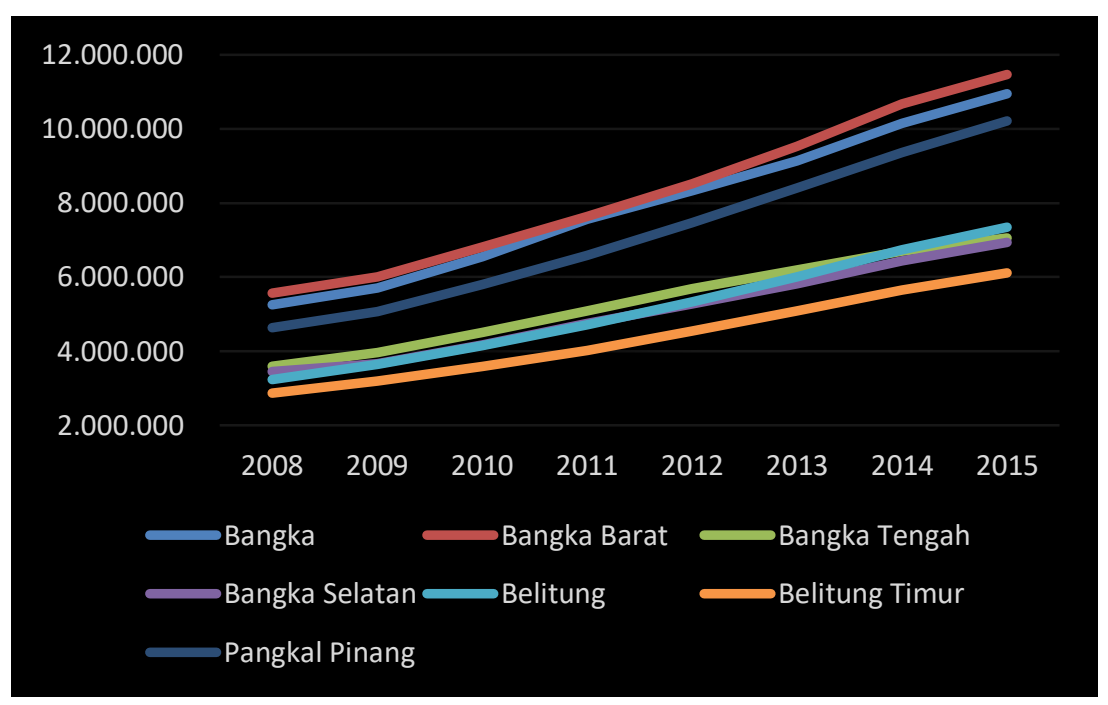

Gambar 2: PDRB Kabupaten/Kota Di Provinsi Kepulauan Bangka Belitung Tahun 2008-2015.

Apabila dilihat dari tren pertumbuhan hanya Kabupaten Bangka Tengah yang memiliki pertumbuhan ekonomi melambat pada periode 2013-2015. Perlambatan tersebut disebabkan perusahaan pertambangan yang memiliki share besar pada PDRB Kabupaten Bangka Tengah tutup disebabkan perlemahan harga komoditas timah dunia yang memiliki efek domino terhadap berkurangnya jumlah ekspor timah Kabupaten Bangka Tengah. Berdasarkan data BPS tahun 2013 pertumbuhan ekonomi Kabupaten Bangka Tengah sebesar 5,22 persen menjadi 0,31 persen pada tahun 2015. Meskipun mengalami perlambatan pertumbuhan perekonomian Kabupaten Bangka Tengah tetap mengalami pertumbuhan positif.

\subsection{Analisis Inferensia}

Dalam analisis regresi data panel ada beberapa tahap yaitu yang pertama memilih model regresi panel terbaik. Model regresi panel yang terbaik dapat berupa common effects model, fixed effects model, atau random effects model. 
Tabel 2. Nilai Statistik Uji Dan P-value Dari Chow Test, Hausman Test, LM-Test Dan $\lambda_{L M}$ test

\begin{tabular}{lcc}
\hline Jenis Uji & Nilai Statistik Uji & P-Value \\
\hline Chow Test & 15,811838 & 0,0000 \\
Hausman Test & 6,319403 & 0,3884 \\
LM-Test & 6,605826 & 0,0000 \\
Statistik Uji $\lambda_{\text {LM }}$ & 49,72793 & 0,0000 \\
\hline
\end{tabular}

Berdasarkan hasil dari Chow test (Tabel 2) dengan tingkat kepercayaan 95 persen dapat diketahui jika model fix effect lebih baik jika dibandingkan model common effect hal ini dapat diketahui dari tabel dari p-value < alpha. Dilanjtukan dengan hausaman test dengan tingkat kepercayaan 95 persen dapat diketahui jika fix effect lebih baik jika dibandingkan dengan random effect, hal ini dapat diketahui dari p-value > alpha. Berdasarkan hasil dari chow test dan hausman test dengan tingkat kepercayaan 95 persen dapat diketahui model terbaik adalah model regresi data panel fix effect. Sehingga dilakukan langkah kedua yaitu melakukan Uji struktur varians-kovarians model. Berdasarkan hasil uji LM-test dengan tingkat kepercayaan 95 persen dapat diketahui jika struktur varians-covarians residual heteroskedastik, hal ini dapat diketahui dari p-value $L M$-test < alpha. Sehingga perlu dilakukan $\lambda_{L M}$ test untuk mengetahui apakah ada korelasi antar individu residual. Berdasarkan $\lambda_{L M}$ test dengan tingkat kepercayaan 95 persen dapat diketahui jika struktur varians-covarians residual heteroskedastik dan ada cross sectional correlation (Seemingly Uncorrelated Regression), hal ini dapat diketahui dari p-value < alpha. Berdasarkan hasil $L M$-test dan $\lambda_{L M}$ test dapat diketahui jika model terbaik adalah Fix effect dengan metode estimasi Seemingly Uncorrelated Regression (SUR).

Setelah melakukan uji struktur varians dan covarians serta pembentukan model maka langkah selanjutnya adalah pengujian asumsi klasik Yaitu uji asumsi normalitas, homoskedastisitas, non-multikolinieritas dan non-autokorelasi.

Tabel 3. Nilai Statistik Uji Dan P-value Dari Jarque Berra Test Dan Durbin Watson Test

\begin{tabular}{lcc}
\hline \multicolumn{1}{c}{ Jenis Uji } & Nilai Statistik Uji & P-Value \\
\hline Jarque Berra Test & 0,218090 & 0,896690 \\
Durbin Watson Test & 2,227979 & - \\
\hline
\end{tabular}

Dengan tingkat kepercayaan 95 persen dapat diketahui jika model fix effect telah memenuhi asumsi normalitas karen $p$-value Jarque Berra Test $>0,05$ (Tabel 3). Apabila dilihat nilai dirbin watson Dengan tingkat kepercayaan 95 persen dapat diketahui jika model fix effect telah memenuhi asumsi non autokorelasi hal ini disebabkan nilai durbin Watson berada $\mathrm{d} u<\mathrm{d}_{\rho}<4-\mathrm{du}$. Untuk asumsi Homoskedastisitas dapat diketahui dari nilai varians dan covarians yang seragam.

Sedangkan untuk asumsi homoskedastisitas telah terpenuhi disebabkan nilai dari varians dan covarians residual fix effect model dengan metode SUR relative seragam hal ini mengindikasikan jika residual model fix effect dengan metode SUR telah memenuhi asumsi Homoskedastis. Untuk asumsi non multikolinieritas berdasarkan 
Nash dan David (2001) sendiri menyebutkan bahwa suatu variabel bebas memiliki korelasi yang tinggi dengan variabel lainnya jika nilai $r$ melebihi 0,85 atau VIF dibawah 5. Apabila kita lihat nilai VIF di Tabel 4 maka dapat diketahui jika model fix effect telah memenuhi asumsi non multikolinieritas disebabkan semua nilai VIF antar variabel bebas dibawah 5 .

Tabel 4. Nilai VIF Variabel Independen

\begin{tabular}{lc}
\hline \multicolumn{1}{c}{ Variabel } & VIF \\
\hline LN_CPO & 1,052 \\
TPT & 1,277 \\
Persentase Penduduk & \\
Miskin & 1,422 \\
TPAK & 1,055 \\
IPM & 1,682 \\
Gini Ratio & 1,037 \\
\hline
\end{tabular}

Setelah model telah memenuhi asumsi gauss markov selanjutnya adalah melakukan uji keberartian model. Nilai adjusted $R$-square yang semakin mendekati satu berarti model semakin baik dalam menjelaskan variasi yang terjadi pada variabel dependen. Berdasarkan model yang terpilih, nilai adjusted $R$-square yang dihasilkan adalah sebesar 0,998 (Tabel 5) yang berarti bahwa variabel-variabel bebas yang digunakan mampu menjelaskan variasi pada variabel dependen sebesar $99,8 \%$, sedangkan $0,20 \%$ sisanya dijelaskan oleh variabel lain di luar pemodelan. Berdasarkan hasil yang diperoleh dapat dilihat bahwa model sudah cukup baik untuk menjelaskan variabel yang mempengaruhi pertumbuhan ekonomi.

Tabel 5. Nilai Statistik Uji Dan P-value Dari F-Test, T-Test Dan Nilai Adjusted R-Square

\begin{tabular}{llcccc}
\hline \multirow{2}{*}{$\begin{array}{l}\text { Variabel } \\
\text { Independent }\end{array}$} & \multicolumn{2}{c}{ F-test } & \multicolumn{2}{c}{$t$-test } & Adjusted $R$ - \\
\cline { 2 - 4 } \multicolumn{1}{c}{ C } & Statistik Uji & p-value & $\begin{array}{c}\text { Statistik } \\
\text { Uji }\end{array}$ & p-value & Square \\
\hline Penduduk & & & 28,713 & 0.000 & \\
Miskin & & & $-38,578$ & 0.000 & \\
TPAK & 2683,927 & 0,0000 & $-30,066$ & 0.000 & \\
IPM & & & 24,398 & 0.000 & 0,998 \\
GINI RATIO & & $-10,912$ & 0.000 & \\
LNCPO & & $-3,786$ & 0.001 & \\
TPT & & 6,329 & 0.000 & \\
\hline
\end{tabular}

Nilai probabilitas F-test adalah sebesar 0,000 yang memberikan keputusan tolak $\mathrm{H}_{0}$. Artinya dengan tingkat kepercayaan 95\% dapat disimpulkan bahwa paling tidak terdapat satu variabel bebas yang memengaruhi pertumbuhan ekonomi di Provinsi Kepulauan Bangka Belitung secara signifikan. Setelah melihat hasil uji simultan, maka langkah selanjutnya adalah melihat hasil pengujian secara parsial masingmasing variabel bebas melalui nilai probabilitas t statistiknya. Berdasarkan Tabel 5 di ketahui jika $p$-value yang diperoleh oleh variabel persentase penduduk miskin, Tingkat 
partisipasi Angkatan kerja (TPAK), Tingkat Pengangguran Terbuka (TPT), Indeks Pembangunan Manusia (IPM), Gini Ratio dan harga crude palm oil dunia sebesar 0,000 . Sehingga dengan tingkat kepercayaan $95 \%$ dapat disimpulkan bahwa variabel bebas yang memengaruhi pertumbuhan ekonomi di Provinsi Kepulauan Bangka Belitung secara signifikan adalah persentase penduduk miskin, Tingkat partisipasi Angkatan kerja (TPAK), Tingkat Pengangguran Terbuka (TPT), Indeks Pembangunan Manusia (IPM), Gini Ratio dan harga crude palm oil dunia.

Setelah dilakukan uji keberartian model maka di lanjutkan dengan tahap interpretasi model, model fix effect dengan metode SUR yag terbentuk adalah sebagai berikut :

Ln_PDRB Bangkat $\quad=11,130-0,536$ Gini_RatioBangkat $^{*}+0,099$ IPMBangkat $^{*}-0,005$ TPAK $_{\text {Bangkat }}{ }^{*}-0,111$ PenmisBangkat ${ }^{*}+0,003$ TPT $_{\text {Bangkat }}{ }^{*}-$ 0,111 LN_CPO Bangkat $^{*}+\varepsilon_{\text {Bangkat }}$

Ln_PDRB BangkaBaratt $=10,829-0,536$ Gini_RatioBangkaBaratt ${ }^{*}+0,099$ IPMBangkaBaratt $^{*}-$ 0,005 TPAK $_{\text {BangkaBaratt }}{ }^{*}-0,111$ PenmisBangkaBaratt ${ }^{*}+0,003$ TPT $_{\text {BangkaBaratt }}{ }^{*}-0,111 \mathrm{LN} \_C P O_{\text {BangkaBaratt }}{ }^{*}+\varepsilon_{\text {BangkaBaratt }}$

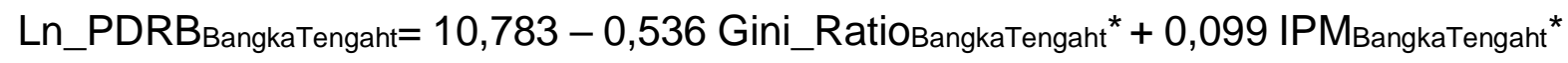
$-0,005$ TPAK $_{\text {BangkaTengaht }}{ }^{*}-0,111$ PenmisBangkaTengaht ${ }^{*}+0,003$ TPT $_{\text {BangkaTengaht }}{ }^{*}-0,111$ LN_CPOBangkaTengaht ${ }^{*}+\varepsilon_{\text {BangkaTengaht }}$

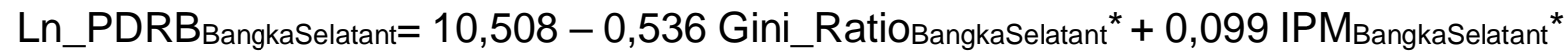
$-0,005$ TPAK $_{\text {BangkaSelatant }}{ }^{\star}-0,111$ PenmisBangkaSelatant ${ }^{*}+0,003$ TPT $_{\text {BangkaSelatant }}{ }^{*}-0,111$ LN_CPOBangkaSelatant ${ }^{*}+\varepsilon_{\text {BangkaSelatant }}$ Ln_PDRBBelitungt $=11,067-0,536$ Gini_RatioBelitungt $^{*}+0,099$ IPMBelitungt $^{*}-0,005$ TPAK $_{\text {Belitungt }}{ }^{*}-0,111$ PenmisBelitungt ${ }^{*}+0,003$ TPT $_{\text {Belitungt }}{ }^{*}-$ 0,111 LN_CPOBelitungt ${ }^{*}+\varepsilon_{\text {Belitungt }}$

Ln_PDRB BelitungTimurt= 10,714 - 0,536 Gini_RatioBelitungTimurt ${ }^{*}+$ 0,099 IPMBelitungTimurt ${ }^{*}-$ 0,005 TPAK BelitungTimurt $^{*}-0,111$ PenmisBelitungTimurt ${ }^{*}+0,003$ TPT $_{\text {BelitungTimurt }}{ }^{*}-0,111 L L_{-}{ }_{\text {CPO Belitung Timurt }}{ }^{*}+\varepsilon_{\text {BelitungTimurt }}$ Ln_PDRBPangkalpinangt $=10,599-0,536$ Gini_RatioPangkalpinangt ${ }^{*}+0,099$ IPMPangkalpinangt ${ }^{*}$ $-0,005$ TPAK $_{\text {Pangkalpinangt }}{ }^{*}-0,111$ PenmiSPangkalpinangt ${ }^{*}+0,003$

TPT Pangkalpinangt $^{*}-0,111$ LN_CPOPangkalpinangt ${ }^{*}+\varepsilon$ Pangkalpinangt

* Signifikan pada alpha $=5 \%$

Variabel persentase penduduk miskin memiliki pengaruh negatif terhadap pertumbuhan ekonomi di Provinsi Kepulauan Bangka Belitung. Nilai koefisien regresi persentase penduduk miskin adalah $-0,111$. Ini berarti setiap peningkatan persentase penduduk miskin sebesar 1 persen maka akan menghambat pertumbuhan ekonomi sebesar 0,111 persen dengan asumsi ceteris paribus. Ketimpangan pendapatan 
berpengaruh negatif terhadap pertumbuhan ekonomi. Nilai koefisien regresi ketimpangan pendapatan adalah $-0,536$ persen dengan asumsi ceteris paribus. Ini berarti apabila ketimpangan pendapatan penduduk meningkat 1 persen maka akan menghambat pertumbuhan ekonomi sebesar 0,536 persen dengan asumsi ceteris paribus. IPM berdampak positif terhadap pertumbuhan ekonomi. Nilai koefisien regresi IPM adalah 0,099. Ini berarti apabila kualitas sumber daya manusia yang tercermin dari IPM meningkat sebesar 1 persen maka akan meningkatkan pertumbuhan ekonomi sebesar 0,099 persen dengan asumsi ceteris paribus. Disini TPAK berpengaruh negatif sedangkan TPT berpengaruh positif terhadap pertumbuhan ekonomi hal ini disebabkan di Provinsi Kepulauan Bangka Belitung didominasi oleh tenaga kerja yang berpendidikan kurang memadai serta sedang masa transisi dari lapangan usaha utama di sektor pertambangan menjadi sektor non pertambangan, apabila tenaga kerja di provinsi didominasi oleh tenaga kerja yang memiliki pendidikan tinggi serta masa transisi lapangan usaha utama tersebut telah selesai maka kemungkinan TPAK akan memiliki pengaruh positif dan TPT akan berpengaruh negatif terhadap pertumbuhan ekonomi.

\section{Simpulan}

Berdasarkan analisis regresi data panel dapat diketahui jika Indeks Pembangunan Manusia, Persentase Penduduk Miskin, TPT, TPAK, Gini Ratio dan harga komoditas dunia mempengaruhi pertumbuhan ekonomi kabupaten/kota di Provinsi Kepulauan Bangka Belitung secara signifikan dengan alpha 5 persen. Indeks Pembangunan Manusia memiliki Pengaruh Positif bagi pertumbuhan ekonomi sedangkan persentase penduduk miskin memiliki pengaruh negatif bagi pertumbuhan ekonomi. Sehingga untuk meningkatkan pertumbuhan ekonomi Provinsi Kepulauan Bangka Belitung ada beberapa solusi yang dapat diterapkan pemerintah yaitu meningkatkan kualitas sumber daya manusia dengan memberikan beasiswa bagi anak yang kurang mampu namun memiliki prestasi serta meningkatkan fasilitas kesehatan didaerah yang masih minim fasilitas kesehatan.

\section{Daftar Pustaka}

Aigheyisi, O. S. (2013). Economic Growth and Human Development Effect of Globalization in Nigeria: Evidence in the Democratic Era. Journal of Economic and Sustainable Development 4(12): 24-33.

Baltagi, B.H. (2005). Econometric Analysis of Panel Data. Third Edition. Chichester: John Wiley \& Sons, Ltd.

Makaringe, S. C., \& Khobai, H. (2018). The effect of unemployment on economic growth in South Africa (1994-2016). MPRA Paper No 85305.

Denison, E. F. (1962). Sources of economic growth in the United States and the alternatives before us. Supplementary Paper, No.13.

Greene, W. H. (2000). Econometric analysis. Fourth Edition. New Jersey: Prentice Hall.

Gujarati, D. N. (2003). Basic Econometric. Fourth Edition. New York: McGraw-Hill Companies. 
Hill, R. C., Griffiths, W. E., \& Lim, G. C. (2011). Principles of econometrics. Fourth Edition. Chichester: John Wiley \& Sons.

Kalsum, U. (2017). Pengaruh Pengangguran dan Inflasi terhadap Pertumbuhan Ekonomi di Sumatera Utara. Jurnal Ekonomikawan, 17(1): 87-94.

Kutner, M. H., Nachtsheim, C. J., Neter, J., \& Li, W. (2005). Applied linear statistical models (Vol. 5). New York: McGraw-Hill Companies.

Adioetomo, S. M., \& Samosir, O. B. (2010). Dasar-dasar Demografi. Jakarta: Salemba Empat.

Nash, M. S., \& Bradford, D. F. (2001). Parametric and nonparametric logistic regressions for prediction of presence/absence of an amphibian. US Environmental Protection Agency, Office of Research and Development, National Exposure Research Laboratory, Environmental Sciences Division.

Tian, Y. (2012). The effect of income inequality on economic growth in China. Economics \& Business Journal: Inquiries \& Perspectives, 4(1), 150-157.

United Nation. (2009). System of national accounting 2008. United States: PBM Graphics.

United Nation. (2014). Human development report 2014. United States: PBM Graphics.

Todaro, M.P. dan S.C. Smith. (2003). Pembangunan Ekonomi di Dunia Ketiga. Jilid 1. Edisi Kedelapan. Jakarta: Erlangga.

Wibisono, D. (2003). Riset Bisnis. Jakarta: Rajawali Pers. 